\title{
EFEKTIVITAS PENERAPAN PIDANA MATI TERHADAP TINDAK PIDANA NARKOTIKA DI INDONESIA
}

\author{
IFAHDA PRATAMA HAPSARI,SH.,MH \\ Universitas Muhammadiyah Gresik \\ ifa.zeggeg@gmail.com
}

\begin{abstract}
The granting of severe penalties for the perpetrators of narcotics crimes is very appropriate to stem and reward the perpetrators of narcotics crimes in accordance with the rules set by the State through existing laws, even with the most severe penalties, namely the Criminal Penalty. differing views on the execution of the death penalty, especially for perpetrators of drug offenses caused by multi-interpretation regulations. In addition, factors outside the law, such as community saturation of drug crimes that are not subject to strict punishment, religious background of society, and social conditions of society are other aspects that greatly affect the community and law enforcers differently in seeing the death penalty for perpetrators drug crimes in Indonesia. In formulating regulations, a punishment tool should include two things, namely: First, must accommodate the aspirations of the people who demand revenge as a balance on the basis of the wrongdoing of the perpetrator. Second, it must include the purpose of punishment in the form of maintaining community solidarity, punishment must be directed at maintaining and maintaining community unity. In this context, when the Indonesian people want the application of the death penalty for drug offenders, their will cannot be banned.
\end{abstract}

Keywords: Effectiveness, Dead Criminal and Criminal Drug.

\section{Latar Belakang Masalah}

Permasalahan hukum yang paling menonjol dapat diidentifikasikan pada kasus pidana yakni penganiayaan, pembunuhan, pencurian dan psikotropika/ narkotika. Narkotika, psikotropika dan zat adiktif lainnya (Napza) yang biasa disebut narkoba merupakan jenis obat/zat yang diperlukan dalam di dunia pengobatan. Akan tetapi apabila dipergunakan tanpa pembatasan dan pengawasan 
yang seksama dapat menimbulkan ketergantungan serta dapat membahayakan kesehatan bahkan jiwa pemakainya.

Penyalahgunaan Narkotika pada akhir-akhir ini dirasakan semakin meningkat. Dapat kita amati dari pemberitaan-pemberitaan baik di media cetak maupun elektronika yang hampir setiap hari memberitakan tentang penangkapan para pelaku penyalahgunaan narkotika oleh aparat keamanan.

Pada dasarnya Narkotika di Indonesia merupakan obat yang dibutuhkan dalam pelayanan kesehatan, sehingga ketersediaannya perlu dijamin. Di lain pihak narkotika dapat menimbulkan ketergantungan apabila disalahgunakan, sehingga dapat mengakibatkan gangguan fisik, mental sosial, keamanan, ketertiban masyarakat yang pada akhirnya menganggu ketahanan nasional.

Penyalahgunaan Narkotika tidak terlepas dari sistem hukum positif yang berlaku di Negara Indonesia. Sistem hukum positif yang berlaku di Negara Indonesia mengalami perkembangan yang sangat pesat, hal ini terlihat dalam efektifnya pelaksanaan sanksi pidana. Dalam Undang-undang No. 35 Tahun 2009 tentang Narkotika (Selanjutnya disingkat Undang-Undang Narkotika) terdapat beberapa sanksi, seperti sanksi pidana mati, pidana penjara, pidana kurungan, maupun sanksi pidana denda dan penerapannya dilakukan secara kumulatif. Agar penggunaan narkotika dapat memberikan manfaat bagi kehidupan umat manusia, peredarannya harus di awasi secara ketat sebagaimana diatur dalam Pasal 7 Undang-Undang Narkotika. Dalam Undang-Undang ini terdapat suatu hukuman yang menimbulkan polemik yaitu Pidana Mati, polemik ini misalnya mengatakan bahwa pidana mati tersebut bertentangan dengan Undang-Undang Dasar 1945 dan ada juga yang mengatakan bahwa pidana mati masih perlu diterapkan untuk memberikan efek jera terhadap pelaku kejahatan narkotika.

Berdasarkan Undang-undang Narkotika pada Pasal 8 ayat (1) isinya menyatakan bahwa:

"Narkotika Golongan I dilarang digunakan untuk kepentingan pelayanan kesehatan."

Dan dalam Pasal 8 ayat 2 isinya menyatakan bahwa ; 
"Dalam jumlah terbatas, Narkotika Golongan I dapat digunakan untuk kepentingan pengembangan ilmu pengetahuan dan teknologi dan untuk reagensia diagnostik, serta reagensia laboratorium setelah mendapatkan persetujuan Menteri atas rekomendasi Kepala Badan Pengawas Obat dan Makanan.”

Seperti yang dikemukakan dalam penggolongan narkotika golongan I mempunyai potensi yang sangat tinggi mengakibatkan ketergantungan. Oleh karena itu di dalam penggunaannya diperuntukkan untuk tujuan pengembangan ilmu pengetahuan dan tidak dipergunakan dalam terapi. ${ }^{1}$

Penjatuhan pidana/pemidanaan memang mustahil menghapuskan kejahatan dimuka bumi tetapi paling tidak pemidanaan berakibat pada kesadaran hukum dari korban-korban menjadi dapat diwujudkan, oleh sebab itu pemidanaan termasuk didalamnya pidana mati bertujuan untuk mewujudkan tujuan hukum, yaitu keadilan, kemanfaatan dan kepastian hukum.

Berdasarkan pada pemaparan di atas, penulis merumuskan masalah yang akan dikaji dalam penelitian ini yaitu Bagiamankah efektivitas sanksi pidana mati terhadap pelaku penyalahgunaan Narkotika di Indonesia.

\section{Analisa dan Pembahasan}

\section{A. Dasar Hukum Pemidanaan terhadap Tindak Pidana Narkoba menurut Undang-Undang Narkotika dan Psikotropika}

Setelah Indonesia merdeka, diadakan penataan dalam perundangan-undangan nasional. Undang-undang yang lahir pada jaman kemerdekaan mengenai Narkotika adalah Undang-Undang Nomor 9 tahun 1976. Cakupan dan substansi yang diatur dalam Undang-undang ini lebih luas dengan disertai ancaman pidana yang lebih berat. Tahun berganti dengan bentuk perkembangan yang makin maju serta globalisasi yang melanda setiap sisi dan aspek hidup, menunjukkan bahwa Undang-undang ini dianggap sudah tidak dapat menampung situasi kejahatan yang ada,

\footnotetext{
${ }^{1}$ Hari Sasangka. 2003. Narkotika dan Psikotropika dalam Hukum Pidana. Mandar Maju; Bandung. H. 173
} 
dimana kejahatan narkotika sudah merupakan transnasional crime ${ }^{2}$, maka dibentuklah Undang-Undang Nomor 35 Tahun 2009 tentang Narkotika. Disamping Undang-Undang ini, Undang-Undang yang bersinergi dengan ini yaitu Undang-Undang Nomor 5 Tahun 1997 tentang Psikotropika. Kedua Undang-Undang ini menjadi dasar pemidanaan terhadap pelaku tindak pidana narkotika Pemidanaan dapat diartikan sebagai sistem pemberian atau penjatuhan pidana.

UU Nomor 35 Tahun 2009 diatur bahwa Narkotika di satu sisi merupakan obat atau bahan bermanfaat dibidang pengobatan atau pelayanan kesehatan dan pengembangan ilmu pengetahuan sebagaimana ditegaskan dalam pasal 7, akan tetapi disisi lain dapat pula menimbulkan ketergantungan yang sangat merugikan apabila disalahgunakan atau digunakan tanpa pengendalian dan pengawasan yang ketat serta saksama.Pengawasan dalam hal ini dilakukan Kementerian Kesehatan, cq. Kepala Badan Pengawasan Obat dan Makanan sebagaimana ditegaskan dalam Pasal 11.

Pada UU Narkotika dan UU Psikotropika secara eksplisit tidak dijelaskan pengertian "pengedar Narkotika/Psikotropika". Secara implisit dan sempit dapat dikatakan bahwa, "pengedar Narkotika/Psikotropika" adalah orang yang melakukan kegiatan penyaluran dan penyerahan Narkotika/Psikotropika.

Akan tetapi, secara luas pengertian "pengedar" tersebut juga dapat dilakukan dan berorientasi kepada dimensi penjual, pembeli untuk diedarkan, mengangkut, menyimpan, menguasai, menyediakan, melakukan perbuatan mengekspor dan mengimport "Narkotika/Psikotropika".

Dalam ketentuan UU Narkotika maka "pengedar" diatur dalam Pasal 111, 112, 113, 114, 115, 116, 117, 118, 119, 120, 121, 122, 123, $124,125$.

${ }^{2}$ Ketentuan tersebut terdapat dalam pertimbangan menimbang dari Undang-Undang Nomor 35 tahun 2009 Tentang Nakotika. 
Selanjutnya dalam UU Psikotropika diatur dalam Pasal 59 ayat (1) huruf a, c, Pasal 60 ayat (1) huruf b, c, ayat (2), (3), (4), (5), Pasal 61 dan Pasal 63 ayat (1) huruf a UU Psikotropika.

Pada hakikatnya, kebijakan formulasi sanksi pidana bagi "Pengedar" dan "Pengguna" UU Narkoba Indonesia secara substansial dalam penelitian ini ditekankan terhadap pelanggaran UU Narkotika/UU Psikotropika. M. Cherif Bossouni dalam "Substantive Criminal Law" mengemukan adanya 3 (tiga) kebijakan, yaitu kebijakan formulatif/legislasi, kebijakan aplikatif/yudikatif dan kebijakan administratif/eksekusi. Kebijakan formulatif merupakan kebijakan yang bersifat strategis dan menentukan, oleh karena kesalahan dalam kebijakan legislasi akan berpengaruh terhadap kebijakan aplikatif/yudikatif. ${ }^{3}$ Pengguna adalah orang yang menggunakan zat atau obat yang berasal dari tanaman, baik sintesis maupun semi sintesis yang dapat menyebabkan penurunan atau perubahan kesadaran, hilangnya rasa, mengurangi sampai menghilangkan rasa nyeri, dan dapat menimbulkan ketergantungan, yang dibedakan dalam golongan-golongan sebagaimana terlampir dalam UU Narkotika/Psikotropika.

Dalam ketentuan UU Narkotika maka "pengguna" diatur dalam Pasal 116, 121, 126, 127, 128, 134, dan dalam UU Psikotropika diatur dalam Pasal 36, 37, 38, 39, 40, 41, 59 ayat (1) huruf a, b dan Pasal 62 UU Psikotropika. Implikasi yuridis ketentuan Pasal 4 huruf d, Pasal 54 dan Pasal 127 UU Narkotika untuk menentukan pengguna narkotika korban atau pelaku, yaitu pengguna narkotika sebagai pelaku tindak pidana dan sekaligus sebagai korban.

Pada dasarnya, "pengedar" narkoba dalam terminologis hukum dikategorisasikan sebagai pelaku (daders), akan tetapi “pengguna" dapat dikategorisasikan baik sebagai “pelaku dan/atau korban”. Selaku korban, maka

${ }^{3}$ Satrio Putra Kolopita, Penegakan Hukum Atas Pidana Mati Terhadap Pelaku Tindak Pidana Narkotika, Lex Crimen Vol. II/No.4/Agustus/2013, h. 65. Dapat juga dilihat dalam Lilik Mulyadi Penelitian Asas, Teori, Norma dan Praktik Penerapannya dalam Putusan Pengadilan, Makalah ini dipresentasikan untuk penelitian tentang, "Pemidanaan Terhadap Pengedar dan Pengguna Narkoba: Penelitian Asas, Teori, Norma dan Praktek Penerapannya Dalam Putusan Pengadilan", diselenggarakan oleh Badan Litbang Diklat Hukum Dan Peradilan Mahkamah Agung Republik Indonesia yang diselenggarakan di wilayah Pengadilan Tinggi Jakarta (7-9 Maret 2012), Pengadilan Tinggi Surabaya (14-16 Maret 2012) dan Pengadilan Tinggi Denpasar (20-22 Maret 2012). 
"pengguna" narkoba adalah warga negara yang harus dilindungi, dihormati serta dihormati hak-haknya baik dalam proses hukum maupun dimensi kesehatan dan sosial.

Tujuan pemidanaan dalam UU Narkotika dan Psikotropika disini, sebagaimana tujuan umum yang berlaku dalam hukum pindana, yaitu adalah untuk mejatuhkan pidana tehap seseorang yang telah melakukan suatu tidnak pidana. Secarea khusus dalam UU Narkotika dan Psikotropika adalah terhadap penggunaan narkotika dan psikotropika serta ditujukan bagi peredaran gelap narkotika.

Dalam praktek peradilan, konsekuensi logis dari perumusan normatif UU Narkotika/Psikotropika maka baik terhadap "pengedar" dan "pengguna" dijatuhkan pidana. Adalah wajar, apabila "pengedar" dijatuhkan pidana relatif setimpal dengan kadar perbuatannya. Dalam UU Narkotika “pengedar” diancam dari hukuman mati sampai pidana penjara dan pidana denda.

\section{B. Hukuman Mati Bagi Pelaku Tindak Pidana Narkoba di Indonesia}

Penegakan hukum dalam kaitan penulisan ini adalah bukan hanya dari sisi penegakan hukum pidana saja, melainkan juga dari penegakan hak asasi manusia, karena menyangkut segi hakekat hidup dari manusia. Dipandang dari aspek pidana, jelas bahwa pengedar Narkoba merupakan suatu tindak pidana yang tentunya akan berakibat hukum sesuai dengan yang dinyatakan dalam Pasal 114 ayat 1 dan 2 UU No. 35 Tahun 2009 tentang Narkotika. Dari aspek hak asasi manusia, pengedar Narkoba dapat dikatakan telah merusak generasi muda karena dengan Narkoba hak asasi manusia yang dimiliki generasi muda akan terampas. Selama ini belum ada satupun jenis Narkoba yang berdampak positif pada pemakainya selain untuk tujuan pengobatan yang berada di bawah pengawasan dokter.

Apabila mempertentangkan Hukuman Mati dengan Hak Asasi Manusia, maka perlu dicermati tentang "Pelanggaran terhadap hak asasi manusia" sebagaimana yang dimaksud dalam Pasal 1 angka 6 UU No. 39 Tahun 1999, 
adalah "setiap perbuatan seseorang atau kelompok orang termasuk aparat negara baik disengaja maupun tidak disengaja, atau kelalaian yang secara melawan hukum mengurangi, menghalangi, membatasi, dan atau mencabut hak asasi manusia seseorang atau kelompok orang yang dijamin oleh undang-undang ini, dan tidak mendapatkan atau dikhawatirkan tidak akan memperoleh penyelesaian hukum yang adil dan benar, berdasarkan mekanisme hukum yang berlaku."7 Pada penerapan hukuman mati terhadap pengedar Narkoba secara yuridis telah memenuhi prosedur sebagaimana yang dinyatakan dalam peraturan perundangundangan yang bersangkutan yaitu Undang-undang No. 35 tahun 2009 tentang Narkotika.

Beberapa negara di dunia berbeda pendapat dalam menerapkan hukuman mati. Hampir sama dengan perdebatan tentang tata cara pelaksanaan hukuman mati, maka keberadaan hukuman matipun juga mengalami dinamika. Terdapat negara yang menolak pelaksanaan hukuman mati dan karenanya negara menghapuskan hukuman mati, sedangkan beberapa negara yang lain masih menerapkan pelaksanaan hukuman mati karena dianggap masih dibutuhkan.

Bagi kedua kelompok tersebut, baik yang mendukung maupun yang menentang, keduanya mendasarkan pendapatnya kepada alasan normatif maupun sosiologis. Indonesia misalnya, mayoritas publik atau sekitar 84,1 persen menyatakan setuju dengan hukuman mati yang diberikan kepada pengedar narkoba. "Bagi mereka yang setuju, alasan yang banyak diungkap adalah narkoba merusak generasi muda $(60,8 \%)$, dan dapat menyebabkan efek jera (23, 7\%). Sedangkan publik yang tidak setuju, alasan yang banyak diungkap adalah masih ada jenis hukuman lain yang lebih manusiawi (36, 2\%) dan hukuman mati merupakan pelanggaran hak asasi manusia $(28,4 \%){ }^{4}$

Di samping persoalan pijakan normatif tentang eksistensi hukuman mati yang beragam, perbedaan pendapat di masyarakat maupun otoritas hukum (pembentuk undang-undang, pengadilan, dan kejaksaan) dipengaruhi oleh berbagai faktor, seperti: pemahaman atas ajaran agama, latar belakang budaya, filosofi dan ideologi yang dianut oleh masyarakat, dan otoritas hukum tersebut.

\footnotetext{
${ }^{4}$ http://ejournal.uin-malang.ac.id/index.php/syariah. Di akses Pada tanggal 8 Maret 2019.
} 
Demikian pula, latar belakang individu seperti gender, ras, tingkat ketaatan beragama, kelompok umur dan pandangan-pandangan pribadi tentang kejahatan tertentu juga mempengaruhi posisi dukungan atau penentangan terhadap hukuman mati. Kepentingan atau kebutuhan nasional masing-masing kawasan untuk terustidaknya mempertahankan hukuman mati bagi tindak pidana atau tindak kejahatan-kejahatan tertentu, juga pasti berbeda-beda.

Untuk kasus Indonesia, ketika kepentingan dan kebutuhan nasional dalam pandangan dan keyakinan masyarakat menghendaki hukuman mati untuk dipertahankan dan dilaksanakan atau dihapus dan dihentikan, keduanya harus disikapi secara obyektif. Ketika terdapat suara yang menghendaki dihapuskannya hukuman mati dari hukum positif Indonesia, mereka yang menyuarakannya perlu meyakinkan atau bahkan membuktikan secara empiris bahwa mayoritas masyarakat Indonesia juga memiliki pandangan yang sama dengan mereka. Akan tetapi, ketika mayoritas masyarakat menyuarakan hal yang sebaliknya, bahwa hukuman mati masih perlu dipertahankan dalam hukum positif Indonesia bagi pelaku kejahatankejahatan tertentu yang mengancam kepentingan masyarakat luas, seperti pelaku terorisme; bandar besar narkoba dan pembunuh berencana yang menghilangkan beberapa nyawa manusia. Realitas seperti inipun harus bisa diterima, sekaligus juga berhenti mencatat Indonesia sebagai negara yang tidak menghormati HAM karena masih mempertahankan hukuman mati. ${ }^{5}$

Berdasarkan uraian di atas, dapat dinyatakan bahwa perbedaan pandangan terhadap pelaksanaan hukuman mati khususnya bagi pelaku tindak pidana narkoba di sebabkan oleh peraturan yang multi penafsiran. Namun yang pasti secara formal hukuman mati masih diakui keberlakuannya di Indonesia meskipun dari waktu ke waktu diupayakan untuk meminimalisasi pelaksanaannya. Di samping itu, faktor-faktor di luar hukum, seperti kejenuhan masyarakat terhadap kejahatan narkoba yang kurang mendapat hukuman tegas, latar belakang agama masyarakat, dan kondisi sosial masyarakat adalah aspek lain yang sangat

${ }^{5}$ Agus Purnomo, Hukuman Mati Bagi Tindak Pidana Narkoba di Indonesia Perspektif Sosisologi Hukum, Jurnal Hukum dan Syariah, 2016, h. 7. 
mempengaruhi masyarakat dan penegak hukum berbeda dalam melihat hukuman mati bagi pelaku tindak pidana narkoba di Indonesia.

Hukuman mati bagi pelaku pidana narkoba adalah salah satu hukuman yang masih diterapkan di Indonesia di samping beberapa jenis hukuman lain. Meskipun kontroversial, hukuman mati di Negara ini bukanlah hukuman yang dilarang. Karena itu, dalam pandangan sosiologi hokum, khususnya teori pilihan rasional, sikap dan tindakan masyarakat Indonesia memilih menerapkan hukuman mati bagi pelaku tindak pidana narkoba dapat dibenarkan, sekalipun di negara lain pidana mati tersebut sudah ditiadakan atau dihapuskan. ${ }^{6}$

Selanjutnya, inkonstitusioanal atau tidaknya pidana mati sebenarnya telah terjawab dalam putusan Mahkamah Konstitusi pada Permohonan Pengujian materil Undang-Undang Nomor 22 tahun 1997 Tentang Narkotika terhadap Undang-Undang Dasar 1945 yang diajukan oleh empat terpidana mati kasus narkotika melalui kuasa hukumnya berkenaan dengan inkonstitusionalitas pidana mati yang termaktub di dalam Undang-Undang Nomor 22 tahun 1997 Tentang Narkotika. Berdasarkan putusan Mahkamah Konstitusi tersebut, secara tegas dinyatakan bahwa ancaman pidana mati pada Undang-Undang Nomor 22 tahun 1997 Tentang Narkotika tidaklah bertentangan dengan Konstitusi. Secara analogi dapat ditarik sebuah kesimpulan bahwa pidana mati bukanlah suatu tindakan inkonstituional.

Untuk memperkuat argumen di atas, maka alangkah baiknya penulis memperkuatnya dengan menyajikan bunyi dari Konklusi dari Putusan Mahkamah Konstitusi terhadap permohonan tersebut, yang menyatakan :

Ketentuan Pasal 80 Ayat (1) huruf a, Ayat (2) huruf (a), Ayat (3) huruf a; Pasal 81 Ayat (3) huruf (a); Pasal 82 Ayat (1) huruf a, Ayat 2 (huruf) a dan Ayat (3) huruf a dalam UU Narkotika, sepanjang yang mengenai ancaman pidana mati, tidak bertentangan dengan Pasal 28A dan Pasal 28I ayat (1) UUD 1945.

\footnotetext{
${ }^{6}$ Ibid
} 


\section{Kesimpulan}

Dengan mencermati uraian di atas, Pemberian hukuman yang berat terhadap pelaku kejahatan narkotika sangat tepat untuk membendung dan mengganjar pelaku kejahatan narkotika sesuai dengan aturan yang sudah ditetapkan oleh Negara lewat Undang-undang yang ada, bahkan dengan hukuman yang seberat-beratnya yaitu Pidana Mati. perbedaan pandangan terhadap pelaksanaan hukuman mati khususnya bagi pelaku tindak pidana narkoba di sebabkan oleh peraturan yang multi penafsiran. Di samping itu, factor-faktor di luar hukum, seperti kejenuhan masyarakat terhadap kejahatan narkoba yang kurang mendapat hukuman tegas, latar belakang agama masyarakat, dan kondisi social masyarakat adalah aspek lain yang sangat mempengaruhi masyarakat dan penegak hukum berbeda dalam melihat hukuman mati bagi pelaku tindak pidana narkoba di Indonesia. Dalam merumuskan regulasi, sebuah perangkat pemidanaan hendaknya mencakup dua hal, yakni: Pertama, harus menampung aspirasi masyarakat yang menuntut pembalasan sebagai pengimbangan atas dasar tingkat kesalahan si pelaku. Kedua, harus mencakup tujuan pemidanaan berupa memelihara solidaritas masyarakat, pemidanaan harus diarahkan untuk memelihara dan mempertahankan kesatuan masyarakat. Dalam konteks demikian, ketika masyarakat Indonesia menghendaki penerapan hukuman mati bagi pelaku tindak narkoba, maka kehendak mereka tidak bisa dilarang.

\section{Daftar Pustaka}

\section{Buku-Buku}

Agus Purnomo. Hukuman Mati Bagi Tindak Pidana Narkoba di Indonesia Perspektif Sosisologi Hukum, Jurnal Hukum dan Syariah, 2016.

Hari Sasangka. 2003. Narkotika dan Psikotropika dalam Hukum Pidana. Mandar Maju; Bandung.

Satrio Putra Kolopita, Penegakan Hukum Atas Pidana Mati Terhadap Pelaku Tindak Pidana Narkotika, Lex Crimen Vol. II/No.4/Agustus/2013.

Lilik Mulyadi Penelitian Asas, Teori, Norma dan Praktik Penerapannya dalam Putusan Pengadilan, Makalah ini dipresentasikan untuk penelitian tentang, 
"Pemidanaan Terhadap Pengedar dan Pengguna Narkoba: Penelitian Asas, Teori, Norma dan Praktek Penerapannya Dalam Putusan Pengadilan.

http://ejournal.uin-malang.ac.id/index.php/syariah. Di akses Pada tanggal 8 Maret 2019.

\section{PERATURAN PERUNDANG-UNDANGAN}

Undang-Undang Dasar Negara Republik Indonesia Tahun 1945

Undang-Undang Republik Indonesia Nomor 22 Tahun 1997 Tentang Narkotika (Lembaran Negara Republik Indonesia Tahun 1997 Nomor 67)

Undang-Undang Republik Indonesia Nomor 35 Tahun 2009 Tentang Narkotika ( Lembaran Negara Republik Indonesia Tahun 2009 Nomor 143, Tambahan Lembaran Negara REPUBLIK Indonesia Tahun 2009 Nomor 5062) 